


About IJMA
International Journal of Medical Arts is the Official Scientific Journal
of the Damietta Faculty of Medicine, Al-Azhar University, Egypt
It is an International, Open Access, Double-blind, Peer-reviewed,
monthly-published (starting January 2022) Journal
The First Issue was published in July 2019
Published under the following license: Creative Commons
Attribution-ShareAlike 4.0 International Public License (CC BY-SA
4.0).
The Egyptian Knowledge Bank hosts the web site and supports
IJMA follows the regulations of the International Committee of
Medical Journal Editors
IJMA is a member of the International Society of Managing and
Technical Editors
IJMA is indexed in the "Directory of Open Access Journals"
[Indexed on 15 January 2021], Index Copernicus and J-Gate [29-6-
IJM21].
IJMA Listed in
"Publons", "Academic resource index [ResearchBib]", "Electronics journal
Jibrary", "Eurasian Scientific Journal Index", World Catalogue of Scientific
WorldCat and "Citefactor"




Available online at Journal Website
https://ijma.journals.ekb.eg/
Main Subject [Internal medicine]

Original Article

\title{
Serum Calprotectin: A promising Biomarker for Inflammatory Bowel Disease [IBD]
}

\author{
Nehal Azab ${ }^{[1]}$, Hala Talkhan ${ }^{[1]}$, Dalia Samaha ${ }^{[1]}$, Hagar Elessawy ${ }^{[2]}$, Lamyaa Salem *1] \\ ${ }^{1}$ Department of Clinical Pathology, Faculty of Medicine, Ain Shams University, Cairo, Egypt \\ ${ }^{2}$ Department of Internal medicine, Faculty of Medicine, Ain Shams University, Cairo, Egypt
}

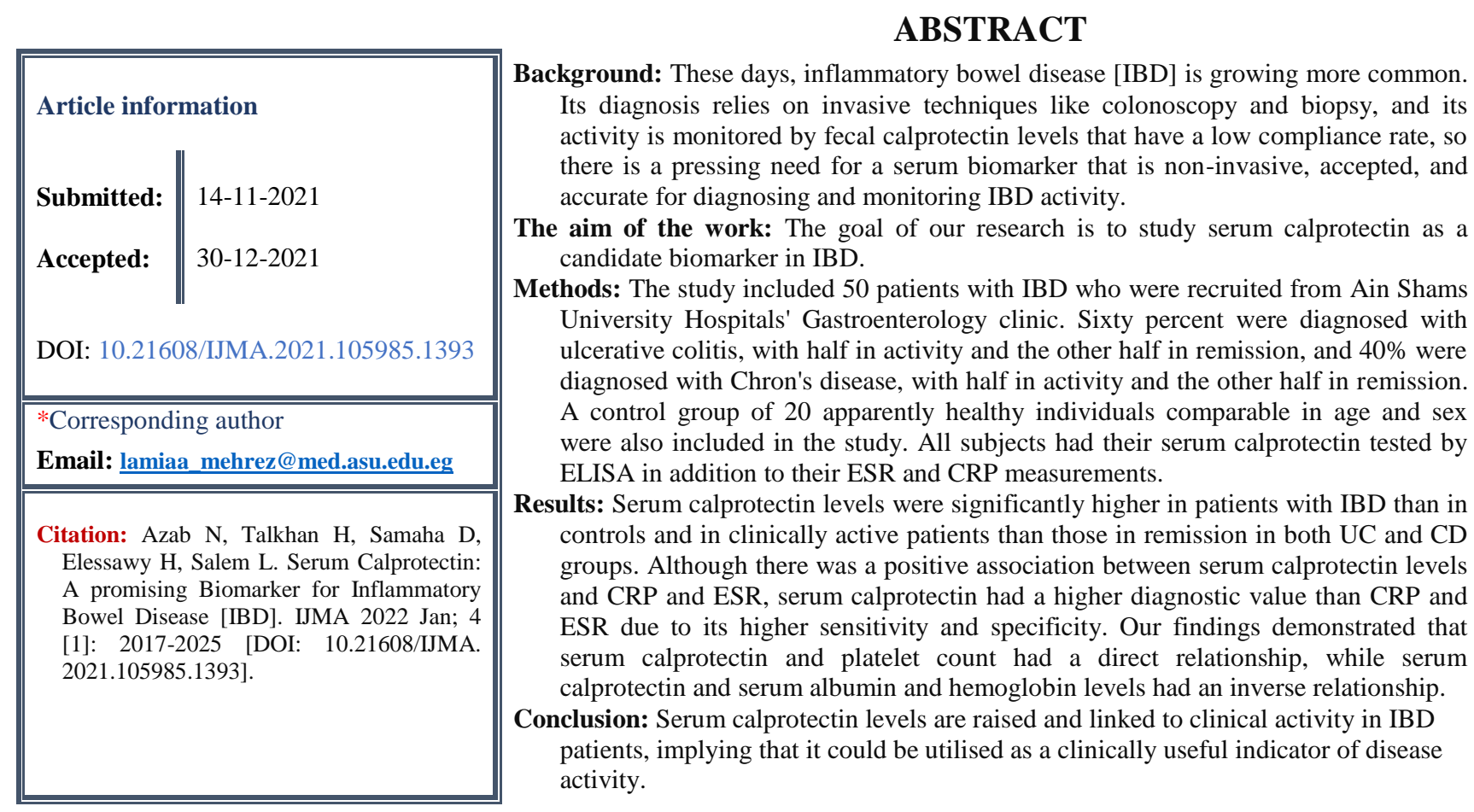

Keywords: Serum calprotectin; Biomarker; Inflammatory bowel disease; Crohn's disease; Ulcerative colitis.

This is an open-access article registered under the Creative Commons, ShareAlike 4.0 International license [CC BY-SA 4.0] [https://creativecommons.org/licenses/by-sa/4.0/legalcode.

\section{INTRODUCTION}

Inflammatory bowel disease [IBD], which encompasses Ulcerative colitis [UC] and Crohn's disease [CD], is a set of gastrointestinal illnesses characterized by chronic inflammation. Although the cause of IBD is unknown many variables including environmental, genetic, and immunologic are thought to play a crucial part in the disease's etiology and pathogenesis. IBD is hypothesized to be the result of a falsely regulated immunological response to the host intestinal microbiota in genetically predisposed individuals ${ }^{[1]}$.

The standard method for initial diagnosis, disease severity assessment, and therapy response evaluation of IBD is presently colonoscopy. For UC, the Mayo Endoscopic Score and for CD, the Simple Endoscopic Score [SES-CD] are two of the most prominent and widely utilized scores in clinical practice. In addition to colonoscopy findings such as erythema, ulcerations, and bleeding, the Mayo 
score is based on the patient's clinical history of stool frequency, rectal bleeding, and general assessment by the clinician ${ }^{[2]}$, while SES-CD is based mostly on ileocolonoscopic findings, such as the number and size of ulcers, as well as the presence and kind of narrowing throughout the colon ${ }^{[3]}$.

The health and financial impact of IBD grows as the disease's incidence rises. The importance of IBD biomarkers is heightened as a result of these alterations. Because colonoscopy is an invasive, costly, and timeconsuming patient procedure, it is vital to develop easy, cheap, and non-invasive IBD diagnostics ${ }^{[4]}$. The serum markers of acute phase response, CRP and ESR, have been explored as IBD biomarkers. They are, however, not limited to IBD, since they are raised in a range of settings such as infections, autoimmune disorders, and cancer ${ }^{[5]}$. Several studies have looked into serum calprotectin as a possible marker for diagnosis of IBD ${ }^{[6]}$.

Calprotectin is made up of two tiny anionic proteins that bind calcium and zinc. Its expression has been found in immune cells such as macrophages, granulocytes, and monocytes during the early stages of differentiation. Calprotectin release weakens cell-cell contacts, causing endothelial permeability to be altered, resulting in leukocyte extravasation ${ }^{[7,8]}$.

\section{THE AIM OF THE WORK}

Our study was prompted by the need for a non-invasive and accurate serum biomarker for IBD diagnosis, activity monitoring and following response to therapy in Egyptian population aiming at introducing serum calprotectin in routine laboratory workup for those patients in the near future.

\section{PATIENTS AND METHODS}

Fifty patients with IBD from Ain Shams University Hospitals' Gastroenterology clinic with ages ranging from 15 to 62 years and 20 apparently healthy subjects comparable in age and sex as a control group were included in this case control study that was conducted in the period between January 2020 and October 2021.

Ethical considerations: All subjects gave a written informed consent before participation and the study was carried out after approval of the Ethical Committee of Ain Shams University [REC FWA 00017585] MS 488/2019. The study protocol conforms to the ethical guidelines of the 16. 1975 Declaration of Helsinki.

Patients with diabetes and obesity were excluded from the study. IBD was diagnosed based on conventional clinical data, which was validated by colonoscopy and biopsy. The Crohn's disease activity index [CDAI] was used to determine the degree of disease activity in the CD group, with a CDAI of less than 150 suggesting remission and greater than or equal to 150 indicating active illness. The modified Truelove and Witts index [TLW] was employed in the UC group, with remission defined as less than or equal 3 and activity defined as $\geq 4^{[9,10]}$.

All of the individuals in the study had a complete medical history taken and a comprehensive clinical assessment. Complete blood count [CBC] was performed using a Coulter counter, ESR was measured using the Westergren method, CRP, serum albumin levels, and serum creatinine levels were all assessed using a Beckman Coulter AU480 autoanalyzer. A quantitative commercially available ELISA kit was used to quantify serum calprotectin [Human Calprotectin ELISA kit, Bioassay Technology laboratory co. cat\# E4010Hu, Shanghai, China].

For the measurement of serum calprotectin; all subjects' venous blood samples were collected on serum separator tubes under strict aseptic conditions using sterile plastic syringes. After allowing the samples to clot for 30 minutes, they were centrifuged at $3000 \mathrm{rpm}$ for 15 minutes, and the serum was removed and kept at $-20^{\circ} \mathrm{C}$. Serum calprotectin was measured using a sandwich ELISA as specified by the manufacturer instructions measuring optical density at $450 \mathrm{~nm}$.

Statistical analysis and interpretation: Data was gathered, edited, coded, and entered into IBM SPSS version 23 [Statistical Package for Social Science] [Armonk, NY]. The quantitative data were presented as mean, standard deviations and ranges when their distribution was found parametric and median 
with inter-quartile range [IQR] when their distribution was found non-parametric. Also, qualitative variables were presented as number and percentages. The $\mathrm{P}$ value was considered significant as follows: $\mathrm{P}$ value $>0.05$ : Nonsignificant, $\mathrm{P}$ value $<0.05$ : Significant.

\section{RESULTS}

According to descriptive statistics of the patient group's demographic data, 33 [66\%] of the 50 patients were females and 17 [34\%] were males, resulting in a female to male ratio of 1.9:1. They ranged in age from 15 to 62 years old, with a mean of $32.68 \pm 10.41$. Thirty patients [60\%] were diagnosed with UC, whereas 20 patients [40\%] were identified as CD [Table 1].

In terms of serum calprotectin levels, there was a statistically significant difference between patients with IBD and the control group, with the patients' group demonstrating a statistically significant rise above the control group $[\mathrm{P}=$ 0.000] [Table 2].

At a cutoff point of $48 \mathrm{ng} / \mathrm{ml}$, serum calprotectin could differentiate between patients with IBD and healthy controls with sensitivity of $98 \%$ and specificity of $95 \%$ with area under the curve [AUC] of 0.991. At a cutoff point of $4.1 \mathrm{mg} / \mathrm{L}, \mathrm{CRP}$ could differentiate between patients with IBD and healthy controls with sensitivity of $64 \%$ and specificity of $85 \%$ with AUC of 0.758 . However, at a cutoff point of 13 $\mathrm{mm} / \mathrm{hr}$ ESR level could differentiate between patients with IBD and healthy controls with sensitivity of $62 \%$ and specificity of $85 \%$ with AUC of 0.703 [Figure1].

Comparison between UC group and CD group revealed no significant change in serum calprotectin, ESR, CRP, hemoglobin levels, platelet count, serum creatinine or serum albumin [P > 0.05] [Table 3].

When clinical and laboratory data from patients with $\mathrm{CD}$ in clinical activity and those in remission were examined, it was shown that patients in clinical activity had higher ESR, CRP and serum calprotectin values than those in remission with a $\mathrm{P}$ value $<0.05$ and had lower albumin and hemoglobin levels [P value $<0.01$ and $<0.05$ respectively]. In addition, there was a statistically significant difference in terms of
SES-CD between both groups. No significant difference in platelet count and serum creatinine levels between the two groups was observed [Table 4].

At a cutoff point of $120 \mathrm{ng} / \mathrm{ml}$, serum calprotectin could differentiate between active cases of $\mathrm{CD}$ and in-remission cases with sensitivity of $90 \%$ and specificity of $90 \%$ with AUC of 0.970 . At a cutoff point of $6.7 \mathrm{mg} / \mathrm{L}$, CRP could differentiate between the two groups with sensitivity of $80 \%$ and specificity of $80 \%$ with AUC of 0.895 . At a cutoff point of 20 $\mathrm{mm} / \mathrm{hr}$, ESR could differentiate between the two groups with sensitivity of $70 \%$ and specificity of $80 \%$ with AUC of 0.770 [Figure 2].

When clinical and laboratory data from patients with UC in clinical activity and those in remission were analyzed, it was shown that patients in clinical activity had higher ESR, CRP, platelet count and serum calprotectin values than those in remission, with a $\mathrm{P}$ value $<0.05$ and had significantly lower albumin and hemoglobin levels [P value $<0.01$ and $\mathrm{P}$ value $<0.05$ respectively]. No significant difference was found in serum creatinine levels or Mayo score between the two groups with a $\mathrm{P}$ value of 0.79 and 0.07 respectively [Table 5].

At a cutoff point of $104 \mathrm{ng} / \mathrm{ml}$, serum calprotectin could differentiate between active cases of UC and in remission cases of UC with sensitivity of $73.33 \%$ and specificity of $93.33 \%$ with AUC of 0.884 . At a cutoff point of 5.8 $\mathrm{mg} / \mathrm{L}, \mathrm{CRP}$ could differentiate between the two groups with sensitivity of $73.33 \%$ and specificity of $93.33 \%$ with AUC of 0.820 . However at a cutoff point of $18 \mathrm{~mm} / \mathrm{hr}$, ESR could differentiate between the two groups with sensitivity of $66.67 \%$ and specificity of 86.67 $\%$ with AUC of 0.711 [Figure 3]

Our results revealed no significant statistical correlation between serum calprotectin levels and age, serum creatinine with $\mathrm{P}$ value $>0.05$. However, there were statistically significant correlation between serum calprotectin and ESR, CRP, hemoglobin level, platelet count, serum albumin, SES-CD, TLW and CDAI with $P$ value $<0.01$. An almost significant statistical correlation was observed between serum calprotectin levels and Mayo score $[\mathrm{P}=0.057]$ [Table 6]. 
Table [1]: Demographic data for the study patients

\begin{tabular}{|l|c|c|}
\hline \multirow{2}{*}{ Gender } & Females & Patients group [No. = 50] \\
\hline Age [years] & Males & $33[66.0 \%]$ \\
& Mean \pm SD & $17[34.0 \%]$ \\
\hline Inflammatory Bowel Disease & Range & $32.68 \pm 10.41$ \\
& Ulcerative colitis & $15-62$ \\
\hline & Crohn's disease & $30[60.0 \%]$ \\
\end{tabular}

Table [2]: Comparison between control and patients' groups regarding serum calprotectin levels

\begin{tabular}{|c|c|c|c|c|}
\hline S. Calprotectin [ng/ml] & Control group & Patients group & Test value & $P$ value \\
\hline & No. $=20$ & No. $=50$ & & \multirow{3}{*}{0.000} \\
\hline Median [IQR] & $20[19-25]$ & $100[76-156]$ & \multirow{2}{*}{$-6.391 \neq$} & \\
\hline Range & $16-68$ & $44-296$ & & \\
\hline
\end{tabular}

Table [3]: Comparison between UC group and CD group regarding laboratory data

\begin{tabular}{|c|c|c|c|c|c|}
\hline & \multicolumn{2}{|c|}{ IBD } & \multirow[t]{3}{*}{ Test value } & \multirow[t]{3}{*}{$P$ value } \\
\hline & & $\mathrm{UC}$ & CD & & \\
\hline & & No. $=30$ & No. $=20$ & & \\
\hline $\operatorname{ESR}[\mathrm{mm} / \mathrm{hr}]$ & $\begin{array}{l}\text { Median [IQR] } \\
\text { Range }\end{array}$ & $\begin{array}{c}15[10-30] \\
5-90\end{array}$ & $\begin{array}{c}20[10-30.0] \\
9-90\end{array}$ & $-1.207 \neq$ & 0.227 \\
\hline $\mathrm{CRP}[\mathrm{mg} / \mathrm{L}]$ & $\begin{array}{c}\text { Median }[\mathrm{IQR}] \\
\text { Range }\end{array}$ & $\begin{array}{c}4.25[2.4-12] \\
0.8-57\end{array}$ & $\begin{array}{c}7.15[4.5-23] \\
0.7-76\end{array}$ & $-1.575 \neq$ & 0.115 \\
\hline Haemoglobin [g/dl] & $\begin{array}{l}\text { Mean } \pm \text { SD } \\
\text { Range }\end{array}$ & $\begin{array}{c}11.89 \pm 1.18 \\
9-14.5\end{array}$ & $\begin{array}{c}11.42 \pm 1.54 \\
6.7-13.5\end{array}$ & $1.212 \bullet$ & 0.232 \\
\hline Platelet count $\left[\times 10^{3} / \mu \mathrm{L}\right]$ & $\begin{array}{c}\text { Mean } \pm \text { SD } \\
\text { Range }\end{array}$ & $\begin{array}{c}255.20 \pm 114.10 \\
138-594\end{array}$ & $\begin{array}{c}246.45 \pm 95.18 \\
157-517\end{array}$ & $0.283 \bullet$ & 0.778 \\
\hline Serum Creatinine [mg/dl] & $\begin{array}{c}\text { Mean } \pm \text { SD } \\
\text { Range }\end{array}$ & $\begin{array}{c}0.93 \pm 0.13 \\
0.7-1.2\end{array}$ & $\begin{array}{c}0.96 \pm 0.24 \\
0.6-1.2\end{array}$ & $-0.543 \bullet$ & 0.590 \\
\hline Serum Albumin [g/dl] & $\begin{array}{c}\text { Mean } \pm \text { SD } \\
\text { Range }\end{array}$ & $\begin{array}{c}3.41 \pm 0.80 \\
2.2-5.2\end{array}$ & $\begin{array}{c}3.42 \pm 0.85 \\
2.4-5.1\end{array}$ & $-0.057 \bullet$ & 0.955 \\
\hline Serum Calprotectin $[\mathrm{ng} / \mathrm{ml}]$ & $\begin{array}{l}\text { Median [IQR] } \\
\text { Range }\end{array}$ & $\begin{array}{c}86[76-156] \\
52-276\end{array}$ & $\begin{array}{c}122[78-156] \\
44-296\end{array}$ & $-0.556 \neq$ & 0.579 \\
\hline
\end{tabular}

$P$ value $>0.05$ : Non significant; $P$ value $<0.05$ : Significant; *: Chi-square test; $\bullet$ : Independent $t$-test; $\neq:$ Mann-Whitney test

Table [4]: Comparison between CD patients in remission and those in activity regarding clinical and laboratory data

\begin{tabular}{|c|c|c|c|c|c|}
\hline & \multicolumn{2}{|c|}{ CD cases } & \multirow{3}{*}{ Test value } & \multirow{3}{*}{$P$ value } \\
\hline & & \multirow{2}{*}{$\begin{array}{l}\text { In remission } \\
\text { No. }=\mathbf{1 0}\end{array}$} & \multirow{2}{*}{$\begin{array}{l}\text { In activity } \\
\text { No. }=\mathbf{1 0}\end{array}$} & & \\
\hline & & & & & \\
\hline ESR $[\mathrm{mm} / \mathrm{hr}]$ & $\begin{array}{c}\text { Median }[\mathrm{IQR}] \\
\text { Range }\end{array}$ & $\begin{array}{c}17.5[10-20] \\
9-30\end{array}$ & $\begin{array}{c}30.0[15-40] \\
10-90\end{array}$ & $-2.064 \neq$ & 0.039 \\
\hline CRP $[\mathrm{mg} / \mathrm{L}]$ & $\begin{array}{c}\text { Median }[\mathrm{IQR}] \\
\text { Range }\end{array}$ & $\begin{array}{c}4.5[2.3-6.7] \\
0.7-20\end{array}$ & $\begin{array}{c}23[7.6-30] \\
5-76\end{array}$ & $-2.989 \neq$ & 0.003 \\
\hline Haemoglobin [g/dl] & $\begin{array}{l}\text { Mean } \pm \text { SD } \\
\text { Range }\end{array}$ & $\begin{array}{c}12.09 \pm 1.17 \\
10-13.5\end{array}$ & $\begin{array}{c}10.75 \pm 1.63 \\
6.7-12.2\end{array}$ & $2.111 \bullet$ & 0.049 \\
\hline Platelet count $\left[\times 10^{3} / \mu \mathrm{L}\right]$ & $\begin{array}{l}\text { Mean } \pm \text { SD } \\
\text { Range }\end{array}$ & $\begin{array}{c}214.30 \pm 50.76 \\
163-300\end{array}$ & $\begin{array}{c}278.60 \pm 119.39 \\
157-517\end{array}$ & $-1.567 \bullet$ & 0.134 \\
\hline Serum Creatinine [mg/dl] & $\begin{array}{l}\text { Mean } \pm \text { SD } \\
\text { Range }\end{array}$ & $\begin{array}{c}1.02 \pm 0.20 \\
0.6-1.2\end{array}$ & $\begin{array}{c}0.89 \pm 0.26 \\
0.6-1.2\end{array}$ & $1.255^{\bullet}$ & 0.225 \\
\hline Serum Albumin [g/dl] & $\begin{array}{l}\text { Mean } \pm \text { SD } \\
\text { Range }\end{array}$ & $\begin{array}{c}4.15 \pm 0.54 \\
3-5.1\end{array}$ & $\begin{array}{c}2.69 \pm 0.20 \\
2.4-3\end{array}$ & $7.952 \bullet$ & 0.000 \\
\hline SES-CD score & $\begin{array}{l}\text { Median [IQR] } \\
\text { Range }\end{array}$ & $\begin{array}{c}2.5[1-3] \\
0-7\end{array}$ & $\begin{array}{c}8[7-12] \\
2-23\end{array}$ & $-3.051 \neq$ & 0.002 \\
\hline Serum Calprotectin [ng/ml] & $\begin{array}{c}\text { Median [IQR] } \\
\text { Range }\end{array}$ & $\begin{array}{c}78[60-100] \\
44-124\end{array}$ & $\begin{array}{c}156[130-180] \\
100-296\end{array}$ & $-3.558 \neq$ & 0.000 \\
\hline
\end{tabular}

$\mathrm{P}$ value $>0.05$ : Non significant; P value $<0.05$ : Significant; $\bullet$ : Independent t-test; $\neq$ : Mann-Whitney test SES-CD score:

Simple Endoscopic Score for CD 
Table [5]: Comparison between UC patients in remission and those in clinical activity regarding clinical and laboratory data

\begin{tabular}{|c|c|c|c|c|c|}
\hline & \multicolumn{2}{|c|}{ UC cases } & \multirow[t]{3}{*}{ Test value } & \multirow[t]{3}{*}{$P$ value } \\
\hline & & \multirow{2}{*}{$\begin{array}{c}\text { In remission } \\
\text { No. }=\mathbf{1 5}\end{array}$} & \multirow{2}{*}{$\begin{array}{l}\text { In activity } \\
\text { No. }=15\end{array}$} & & \\
\hline & & & & & \\
\hline ESR $[\mathrm{mm} / \mathrm{hr}]$ & $\begin{array}{l}\text { Median [IQR] } \\
\text { Range }\end{array}$ & $\begin{array}{c}17.5[10-20] \\
9-30\end{array}$ & $\begin{array}{c}30.0[15-40] \\
10-90\end{array}$ & $-2.064 \neq$ & 0.039 \\
\hline CRP $[\mathrm{mg} / \mathrm{L}]$ & $\begin{array}{c}\text { Median }[\mathrm{IQR}] \\
\text { Range }\end{array}$ & $\begin{array}{c}4.5[2.3-6.7] \\
0.7-20\end{array}$ & $\begin{array}{c}23[7.6-30] \\
5-76\end{array}$ & $-2.989 \neq$ & 0.003 \\
\hline Haemoglobin [g/dl] & $\begin{array}{l}\text { Mean } \pm \text { SD } \\
\text { Range }\end{array}$ & $\begin{array}{c}12.09 \pm 1.17 \\
10-13.5\end{array}$ & $\begin{array}{c}10.75 \pm 1.63 \\
6.7-12.2\end{array}$ & $2.111^{\bullet}$ & 0.049 \\
\hline Platelet count $\left[\times 10^{3} / \mu \mathrm{L}\right]$ & $\begin{array}{c}\text { Mean } \pm \text { SD } \\
\text { Range }\end{array}$ & $\begin{array}{c}214.30 \pm 50.76 \\
163-300\end{array}$ & $\begin{array}{c}278.60 \pm 119.39 \\
157-517\end{array}$ & $-1.567 \bullet$ & 0.134 \\
\hline Serum Creatinine [mg/dl] & $\begin{array}{c}\text { Mean } \pm \text { SD } \\
\text { Range }\end{array}$ & $\begin{array}{c}1.02 \pm 0.20 \\
0.6-1.2\end{array}$ & $\begin{array}{c}0.89 \pm 0.26 \\
0.6-1.2\end{array}$ & $1.255^{\bullet}$ & 0.225 \\
\hline Serum Albumin [g/dl] & $\begin{array}{c}\text { Mean } \pm \text { SD } \\
\text { Range }\end{array}$ & $\begin{array}{c}4.15 \pm 0.54 \\
3-5.1\end{array}$ & $\begin{array}{c}2.69 \pm 0.20 \\
2.4-3\end{array}$ & $7.952 \bullet$ & 0.000 \\
\hline SES-CD score & $\begin{array}{l}\text { Median [IQR] } \\
\text { Range }\end{array}$ & $\begin{array}{c}2.5[1-3] \\
0-7\end{array}$ & $\begin{array}{c}8[7-12] \\
2-23\end{array}$ & $-3.051 \neq$ & 0.002 \\
\hline Serum Calprotectin [ng/ml] & $\begin{array}{l}\text { Median [IQR] } \\
\text { Range }\end{array}$ & $\begin{array}{c}78[60-100] \\
44-124\end{array}$ & $\begin{array}{c}156[130-180] \\
100-296\end{array}$ & $-3.558 \neq$ & 0.000 \\
\hline
\end{tabular}

$\mathrm{P}$ value $>0.05$ : Non significant; $\mathrm{P}$ value $<0.05$ : Significant; $\bullet:$ Independent $\mathrm{t}$-test; $\neq:$ : Mann-Whitney test

Table [6]: Correlation between serum calprotectin and other parameters under study

\begin{tabular}{|l|c|c|} 
& \multicolumn{2}{c|}{ Serum Calprotectin [ng/ml] } \\
\hline Age $[$ years] & $\boldsymbol{r}$ & $\boldsymbol{P}$ value \\
\hline ESR mm/hr & -0.033 & 0.818 \\
\hline CRP $\mathbf{~ m g / L}$ & $0.761^{* *}$ & 0.000 \\
\hline Hemoglobin $[\mathrm{g} / \mathrm{dl}]$ & $0.804^{* *}$ & 0.000 \\
\hline Platelet count $[\mathbf{x 1 0} / \mathbf{M L}]$ & $-0.472^{* *}$ & 0.001 \\
\hline Serum Creatinine $[\mathbf{m g} / \mathbf{d l}]$ & $0.606^{* *}$ & 0.000 \\
\hline Serum Albumin $[\mathrm{g} / \mathbf{d l}]$ & -0.082 & 0.573 \\
\hline Mayo Score & $-0.667^{* *}$ & 0.000 \\
\hline SESCD score & 0.351 & 0.057 \\
\hline TLW for UC & $0.622^{* *}$ & 0.003 \\
\hline CDAI for CD & $0.723^{* *}$ & 0.000 \\
\hline
\end{tabular}

**: Significant at P value $<0.05$; TLW: The modified Truelove and Witts index; CDAI: Crohn's disease activity index

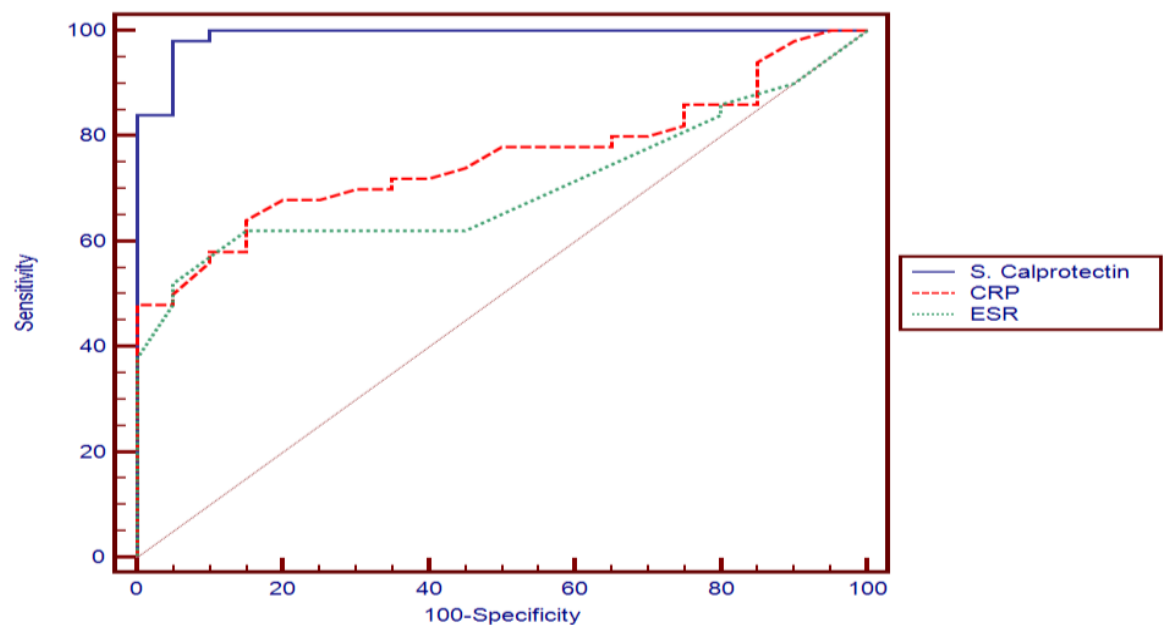

\begin{tabular}{|l|c|c|c|c|c|c|}
\hline \multicolumn{1}{|c}{ Parameters } & Cut off point & AUC & Sensitivity & Specificity & +PV & -PV \\
\hline Serum Calprotectin [ng/ml] & $>48$ & 0.991 & $98.0 \%$ & $95.0 \%$ & $98.0 \%$ & $95.0 \%$ \\
\hline CRP [mg/L] & $>4.1$ & 0.758 & $64.0 \%$ & $85.0 \%$ & $91.4 \%$ & $48.6 \%$ \\
\hline ESR [mm/hr] & $>13$ & 0.703 & $62.0 \%$ & $85.0 \%$ & $91.2 \%$ & $47.2 \%$ \\
\hline
\end{tabular}

Figure [1]: Receiver operating characteristic curve [ROC] for serum calprotectin levels, CRP levels and ESR levels to differentiate between patients and controls 


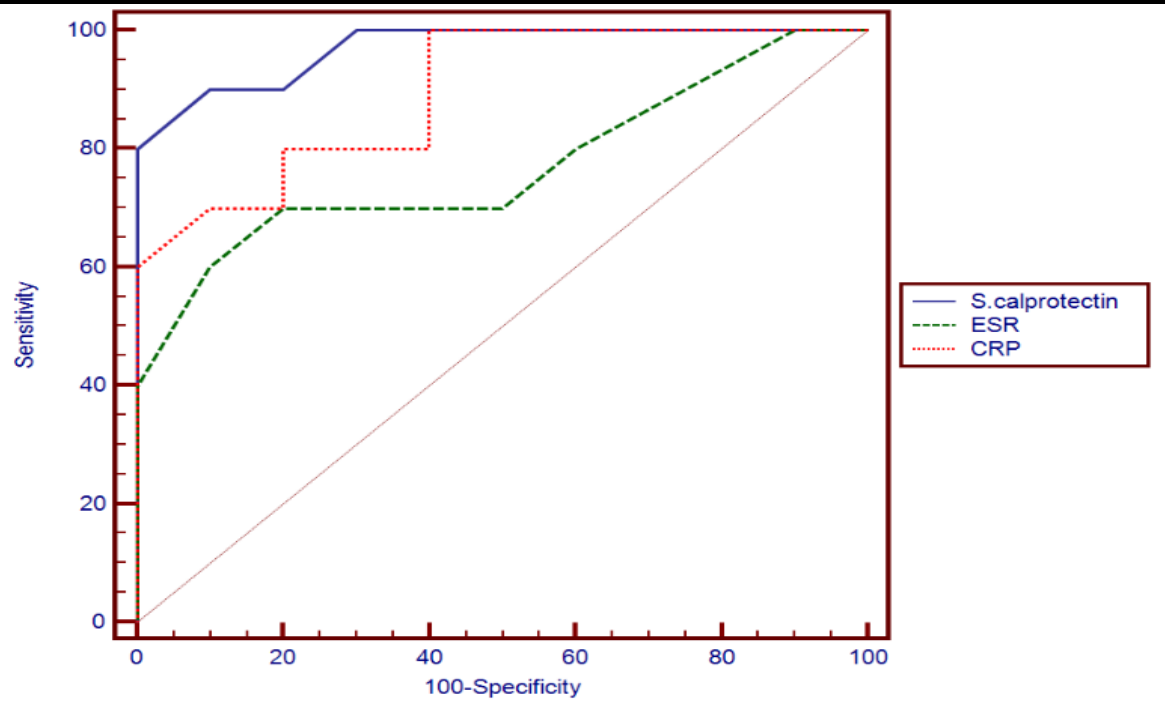

\begin{tabular}{|l|c|c|c|c|c|c|}
\multicolumn{1}{c}{ Parameters } & Cut off point & AUC & Sensitivity & Specificity & +PV & -PV \\
\hline Serum Calprotectin [ng/ml] & $>120$ & 0.970 & $90.0 \%$ & $90.0 \%$ & $90.0 \%$ & $90.0 \%$ \\
\hline CRP [mg/L] & $>6.7$ & 0.895 & $80.0 \%$ & $80.0 \%$ & $80.0 \%$ & $80.0 \%$ \\
\hline ESR [mm/hr] & $>20$ & 0.770 & $70.0 \%$ & $80.0 \%$ & $77.8 \%$ & $72.7 \%$ \\
\hline
\end{tabular}

Figure [2]: Receiver operating characteristic curve [ROC] for serum calprotectin, CRP and ESR to differentiate between active cases and in remission cases in $\mathrm{CD}$ group

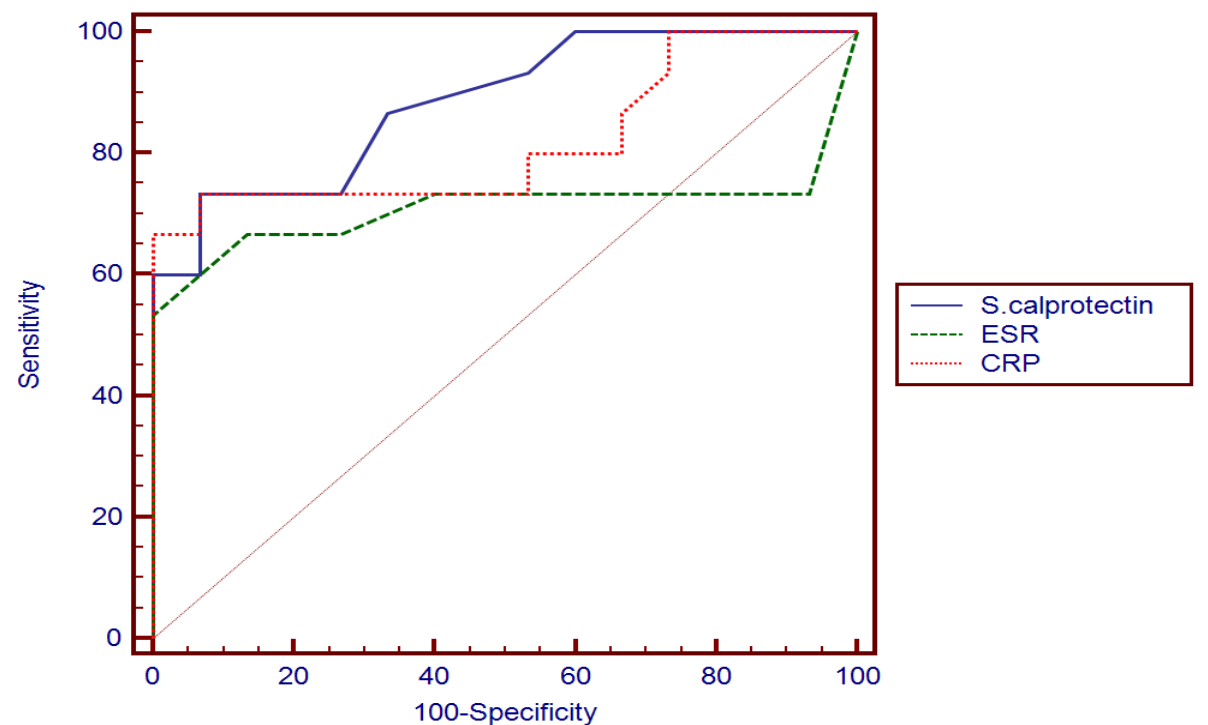

\begin{tabular}{|l|c|c|c|c|c|c|}
\hline \multicolumn{1}{c|}{ Parameters } & Cut off point & AUC & Sensitivity & Specificity & +PV & -PV \\
\hline Serum Calprotectin [ng/ml] & $>104$ & 0.884 & $73.33 \%$ & $93.33 \%$ & $91.7 \%$ & $77.8 \%$ \\
\hline CRP [mg/L] & $>5.8$ & 0.820 & $73.33 \%$ & $93.33 \%$ & $91.7 \%$ & $77.8 \%$ \\
\hline ESR [mm/hr] & $>18$ & 0.711 & $66.67 \%$ & $86.67 \%$ & $83.3 \%$ & $72.2 \%$ \\
\hline
\end{tabular}

Figure (3): Receiver operating characteristic curve (ROC) for serum calprotectin, CRP and ESR to differentiate between active cases and in remission cases in UC group

\section{DISCUSSION}

Inflammatory bowel disease [IBD], namely $\mathrm{UC}$ and $\mathrm{CD}$, are chronic inflammatory illnesses that go through phases of aggravation and remission ${ }^{[11]}$. Patients' quality of life and mental health are much impacted by recurrent IBD, and measuring disease activity can help guide treatment and estimate prognosis ${ }^{[12]}$.

Despite the fact that colonoscopy is the best approach for diagnosing IBD, it is intrusive and costly, hence an urgent demand for non-invasive, accepted, and accurate blood-based biomarkers has emerged [4]. CRP and ESR, two serum indicators of acute phase response, are too little sensitive and specific for intestinal inflammation since their levels are frequently elevated in infections, autoimmune disorders, and other conditions ${ }^{[13]}$. Serum calprotectin has been investigated as an acute phase reactant increasing with IBD exacerbations ${ }^{[11]}$.

Calprotectin is mainly found in neutrophil 
granules and has antimicrobial activity [14]. Calprotectin expression is up-regulated in neutrophils after induction by lipopolysaccharides or chemokines, and it is translocated to the extracellular fluid. It then initiates a many biological processes such as signal transduction, cell homeostasis, and inflammation. It is also involved in the activation of phagocyte NADPH oxidase. Serum calprotectin has been poorly studied, but recent literature suggests a potential role as an inflammatory biomarker in IBD ${ }^{[6]}$.

In our study, serum calprotectin levels in patients with IBD [UC and CD groups] were considerably higher than in the control group $[\mathrm{P}$ $<0.01$, with a sensitivity and specificity of $98 \%$ and $95 \%$, respectively. This is consistent with the findings of Leach et al. ${ }^{[15]}$ and Okada et al. [16], who also found elevated serum calprotectin levels in patients with IBD.

CRP and ESR levels were also shown to differ statistically between IBD patients and control groups. CRP had sensitivity and specificity of $64 \%$ and $85 \%$, respectively, whilst ESR had sensitivity and specificity of $62 \%$ and $85 \%$, demonstrating that serum calprotectin has a stronger diagnostic value for IBD than CRP and ESR. This is in line with the findings of Kalla et al. ${ }^{[17]}$ who studied serum calprotectin levels in 156 individuals and reported that in comparison to other biomarkers such as CRP and serum albumin, serum calprotectin was the best determinant for IBD diagnosis and may signal need for surgery in IBD patients, particularly those with CD. Furthermore, Okada et al. ${ }^{[16]}$ claimed that CRP was found to be a less sensitive and specific biomarker for IBD than serum calprotectin and found no correlation between serum calprotectin and serum albumin, WBC count, or platelet count.

In our investigation, there was no significant change in serum calprotectin, ESR, CRP and other laboratory markers assessed between the $\mathrm{CD}$ and UC groups, which indicates that serum calprotectin, as a biomarker, was not able to distinguish patients with UC from those with CD. Failure of localization of the disease in patients with IBD may be considered a limitation of the present study. These findings were in contrast to the results reported by Okada et al. ${ }^{[16]}$ and Elshayeb et al. ${ }^{[18]}$ who demonstrated higher serum calprotectin levels in patients with
CD than in patients with UC. The discrepancies in outcomes could be explained by ethnic disparities and/or sample sizes.

In the $\mathrm{CD}$ group, the difference in serum calprotectin levels, ESR, CRP, hemoglobin, albumin levels, and SES-CD score between the active and in remission subjects was statistically significant. While in the UC group, the difference in serum calprotectin levels, ESR, CRP, hemoglobin, albumin levels, and platelet count between active and in remission cases was statistically significant.

The sensitivity and specificity of serum calprotectin to differentiate between the active cases and in remission cases in the $\mathrm{CD}$ group were $90 \%$ and $90 \%$ while for CRP they were $80 \%$ and $80 \%$ and for ESR were $70 \%$ and $80 \%$ respectively denoting that serum calprotectin had higher diagnostic characteristics in judging the activity of CD.

The sensitivity and specificity of serum calprotectin to predict disease activity among the UC group were $73.33 \%$ and $93.33 \%$ while for CRP they were $73.33 \%$ and $93.33 \%$; and for ESR were $66.67 \%$ and $86.67 \%$ respectively. The diagnostic characteristics of serum calprotectin were similar to that of CRP but higher than ESR in judging the activity of UC.

Serum calprotectin levels, ESR and CRP were higher in individuals with active IBD both in UC and $\mathrm{CD}$ groups than those in remission. This was consistent with studies by Alper et al. ${ }^{[19]}$ and Megeed et al. ${ }^{[20]}$, who associated ESR and CRP with IBD diagnosis and clinical, endoscopic and radiographic disease activity across time. This was also agreed upon on by Solem et al. ${ }^{[21]}$. This is also in line with the findings of Leach et al. ${ }^{[15]}$, who investigated serum calprotectin in a juvenile IBD population and found it to be substantially linked with disease activity.

In another study, Meuwis et al. ${ }^{[22]}$ examined the role of serum calprotectin as a marker for CD in 115 patients, finding that CD patients had higher serum calprotectin levels than healthy controls. Serum calprotectin levels in active disease were substantially higher than in inactive disease. They came to the conclusion that serum calprotectin, coupled with fecal calprotectin and CRP, might be utilized to predict recurrence after infliximab discontinuation. 
Our findings were similar to those of Malham et al. ${ }^{[23]}$, who demonstrated that higher serum calprotectin levels were linked to a more severe inflammatory state in the colon as well as significant clinical symptoms [i.e., active disease] in UC patients. Furthermore, Chen et al. ${ }^{[12]}$ compared serum calprotectin, CRP, and ESR levels to IBD activity and discovered that serum calprotectin levels had greater sensitivity and specificity than CRP and ESR in predicting IBD activity.

On the other hand, McCann et al. ${ }^{[24]}$ studied the performance of serum calprotectin versus fecal calprotectin and CRP in a group of 109 people with gastrointestinal disorders. They discovered no substantial correlation between serum calprotectin, fecal calprotectin, and CRP. As a result, they came to the conclusion that serum calprotectin is unlikely to be effective as a biomarker for intestinal inflammation.

Our work revealed a positive correlation between serum calprotectin and ESR, CRP and platelet count in patients with IBD; while it had an inverse relation with serum albumin and hemoglobin levels. Similar results were also reported by Leach et al. ${ }^{[15]}$ and Meuwis et al. [22]. It is believed that because of the malabsorbtion of nutrients, serum albumin level decreases in proportion to the IBD activity. Platelet count is increased as an acute phase reactant while hemoglobin levels are decreased due to iron deficiency anemia caused by repeated bleeding from the digestive tract especially during flares of the disease or due to anemia of chronic disease. Anemia is a significant complication of IBD ${ }^{[25]}$.

In the present study there was a significant correlation between serum calprotectin and SES$\mathrm{CD}$ and $\mathrm{CDAI}$ in patients with $\mathrm{CD}$, together with statistically significant correlation between serum calprotectin and TLW in patients with UC. The correlation of serum calprotectin with Mayo score in patients with UC was nearly significant denoting that serum calprotectin was correlated with both clinical and endoscopic features of disease activity of IBD.

Study's limitations: Sample size of this study was relatively small which may have an impact on the generalization of findings so authors recommend the following: a] An extended research on larger number of IBD patients for better evaluation of the relationship between serum calprotectin and IBD clinical activity, studying the best cutoff values in clinical practice for monitoring intestinal inflammation and assessing the utility of serum calprotectin in anticipating IBD relapse and evaluating efficacy of medical therapy, b] Study of serum calprotectin levels together with fecal calprotectin for better evaluation of sensitivity and specificity of serum calprotectin, c] Study of serum calprotectin levels in other inflammatory diseases for better evaluation of its specificity. d] Further studies on how to decrease serum calprotectin for better control of IBD exacerbations.

Conclusion: Serum calprotectin levels are higher in patients with IBD and are related to clinical activity. The association between serum calprotectin, CRP, and ESR was found to be statistically significant. Because of its better sensitivity and specificity, serum calprotectin has a higher diagnostic value for IBD than CRP and ESR. According to our findings, high serum calprotectin levels can distinguish between patients who are clinically active and those who are in remission in both UC and CD groups. Our findings show that serum calprotectin may be a promising simple diagnostic and prognostic biomarker for IBD however more research is needed to reach a judgment in this regard.

Funding sources: None.

\section{REFERENCES}

1. Vedamurthy A, Ananthakrishnan AN. Influence of Environmental Factors in the Development and Outcomes of Inflammatory Bowel Disease. Gastroenterol Hepatol [N Y]. 2019 Feb;15[2]:72-82. PMID: 31011301.

2. Pabla BS, Schwartz DA. Assessing Severity of Disease in Patients with Ulcerative Colitis. Gastroenterol Clin North Am. 2020;49[4]:671-688. DOI: 10.1016/j.gtc. 2020.08.003.

3. Klenske E, Bojarski C, Waldner M, Rath T, Neurath MF, Atreya R. Targeting mucosal healing in Crohn's disease: what the clinician needs to know. Therap Adv Gastroenterol. 2019;12:1756284819856865. DOI: $10.1177 / 1756284819856865$.

4. Gonczi L, Bessissow T, Lakatos PL. Disease monitoring strategies in inflammatory bowel diseases: What do we mean by "tight control"? World J Gastroenterol. 2019 Nov;25[41]:6172-6189. DOI: 10.3748/wjg.v25. i41.6172. 
5. Wakai M, Hayashi R, Tanaka S, Naito T, Kumada J, Nomura M, et al. Serum amyloid $\mathrm{A}$ is a better predictive biomarker of mucosal healing than Creactive protein in ulcerative colitis in clinical remission. BMC Gastroenterol. 2020 Apr 3;20[1]:85. DOI: 10. 1186/s12876-020-01229-8.

6. Azramezani Kopi T, Shahrokh S, Mirzaei S, Asadzadeh Aghdaei H, Amini Kadijani A. The role of serum calprotectin as a novel biomarker in inflammatory bowel diseases: a review study. Gastroenterol Hepatol Bed Bench. 2019 Summer;12[3]:183-189. PMID: 31528300 .

7. Wang S, Song R, Wang Z, Jing Z, Wang S, Ma J. S100A8/A9 in Inflammation. Front Immunol. 2018 Jun 11;9:1298. DOI: 10.3389/fimmu. 2018.01298.

8. Fukunaga S, Kuwaki K, Mitsuyama K, Takedatsu H, Yoshioka S, Yamasaki $\mathrm{H}$, et al. Detection of calprotectin in inflammatory bowel disease: Fecal and serum levels and immunohistochemical localization. Int J Mol Med. 2018 Jan;41[1]:107-118. DOI: 10.3892/ ijmm.2017.3244.

9. Best WR, Becktel JM, Singleton JW, Kern F Jr. Development of a Crohn's disease activity index. National Cooperative Crohn's Disease Study. Gastroenterology. 1976 Mar;70[3]:439-44. PMID: 1248701.

10. Lichtiger S, Present DH. Preliminary report: cyclosporin in treatment of severe active ulcerative colitis. Lancet. 1990 Jul 7;336[8706]:16-9. DOI: 10.1016/0140-6736 [90]91521-b.

11. Bourgonje AR, von Martels JZH, Gabriëls RY, Blokzijl T, Buist-Homan M, Heegsma J, et al. A Combined Set of Four Serum Inflammatory Biomarkers Reliably Predicts Endoscopic Disease Activity in Inflammatory Bowel Disease. Front Med. 2019 Nov 5;6:251. DOI: 10.3389/fmed.2019.00251.

12. Chen RD, Hu YY, Chen Q, Xu H, Qian MJ. Association between Serum Calprotectin Expression and Disease Activity in Patients with Inflammatory Bowel Disease. Indian J Pharm Sci. 2021;83[1]Spl issue1:12-17. DOI: 10.36468/pharmaceuticalsciences.spl.163.

13. Kessel C, Lavric M, Weinhage T, Brueckner M, de Roock S, Däbritz J, et al. Serum biomarkers confirming stable remission in inflammatory bowel disease. Sci Rep. 2021;11[1]:6690. DOI: 10.1038/s41598-021-86251-w.

14. Nakashige TG, Zygiel EM, Drennan CL, Nolan EM. Nickel Sequestration by the Host-Defense Protein Human Calprotectin. J Am Chem Soc. 2017 Jul 5;139[26]:8828-8836. DOI: 10.1021/ jacs.7b01212.

15. Leach ST, Yang Z, Messina I, Song C, Geczy CL, Cunningham AM, Day AS. Serum and mucosal S100 proteins, calprotectin [S100A8/ S100A9] and S100A12, are elevated at diagnosis in children with inflammatory bowel disease. Scand J Gastroenterol. 2007;42[11]: 1321-1331. DOI: 10.1080/
00365520701416709.

16. Okada K, Okabe M, Kimura $\mathrm{Y}$, Itoh H, Ikemoto $\mathrm{M}$. Serum S100A8/A9 as a Potentially Sensitive Biomarker for Inflammatory Bowel Disease. Lab Med. 2019 Oct 10;50[4]:370-380. DOI: 10.1093/labmed/lmz003.

17. Kalla R, Kennedy NA, Ventham NT, Boyapati RK, Adams AT, Nimmo ER, et al. Serum Calprotectin: A Novel Diagnostic and Prognostic Marker in Inflammatory Bowel Diseases. Am J Gastroenterol. 2016 Dec;111 [12]:1796-1805. DOI: 10.1038/ajg.2016.342.

18. Elshayeb EI, Moustafa AE, Helwa MA, Marey AI. Serum calprotectin level: is it a novel diagnostic biomarker for chronic inflammatory bowel diseases? Menouf Med J 2021;34:768-73. DOI: 10.4103/mmj.mmj_29_20.

19. Alper A, Zhang L, Pashankar DS. Correlation of Erythrocyte Sedimentation Rate and C-Reactive Protein With Pediatric Inflammatory Bowel Disease Activity. J Pediatr Gastroenterol Nutr. 2017 Aug;65[2]:e25-e27. DOI: 10.1097/MPG.0000000000001444.

20. El Megeed KHA, Saleh SAB, Mohamed AE, Alphonse Anwar C. Predictors of surgical intervention in patients with inflammatory bowel disease [two-center study]. Egypt J Intern Med. 2021 Jul 8;33[1]. DOI: 10.1186/ s43162-021-00050-3.

21. Solem CA, Loftus EV Jr, Tremaine WJ, Harmsen WS, Zinsmeister AR, Sandborn WJ. Correlation of Creactive protein with clinical, endoscopic, histologic, and radiographic activity in inflammatory bowel disease. Inflamm Bowel Dis. 2005 Aug;11[8]:70712. DOI: 10.1097/01.mib.0000173271.18319.53.

22. Meuwis MA, Vernier-Massouille G, Grimaud JC, Bouhnik Y, Laharie D, Piver E, et al.; GETAID [Groupe d'Étude Thérapeutique Des Affections Inflammatoires Digestives]. Serum calprotectin as a biomarker for Crohn's disease. J Crohns Colitis. 2013;7[12]:e678-83.

DOI: 10.1016/j.crohns.2013.06.008.

23. Malham M, Carlsen K, Riis L, Paerregaard A, Vind I, Fenger M, Wewer V. Plasma calprotectin is superior to serum calprotectin as a biomarker of intestinal inflammation in ulcerative Colitis. Scand J Gastroenterol. 2019; 54[10]:1214-1219. DOI: 10.1080/00365521. 2019.1665097.

24. McCann RK, Smith K, Gaya DR. A prospective single centre pilot evaluation of a serum calprotectin assay in unselected GI patients. Clin Biochem. 2017 Jun;50[9]:533-536. DOI: 10.1016/j.clinbiochem. 2017.01.006.

25. Jimenez KM, Gasche C. Management of Iron Deficiency Anaemia in Inflammatory Bowel Disease. Acta Haematol. 2019;142[1]:30-36. DOI: $10.1159 / 000496728$. 


\section{$1=\sqrt{202(2)}$}

international Journal https://ijma.journals.ekb.eg/ Print ISSN: 2636-4174 Online ISSN: 2682-3780

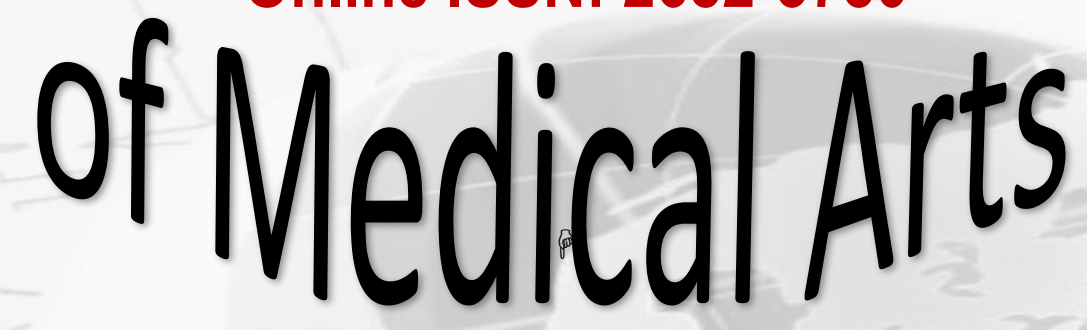

